\title{
Welcome to the Food Production, Processing and Nutrition journal
}

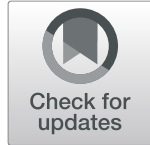

Fereidoon Shahidi ${ }^{{ }^{*}}$ and Jianrong Shi ${ }^{2}$

Food production, processing and nutrition is a multifaceted area of research and development, of interest to many, which has both fundamental and applied components of interest. The field has undergone rapid advances in each of its components which starts with the food production, whether land-based farms or aquatic areas related to fisheries and aquaculture, to gene manipulation, variety improvement and selection as well as further studies that include proteomic, lipidomic and foodomic, among others. Furthermore, green processing, food safety, elimination of contaminants and retention of bioactive components using both thermal and non-thermal processing, are rapidly expanding our horizons. Of course, full attention must also be paid to ultra-processed foods that may provide variety but this could come at the price of including components that may lead to obesity and other health concerns if not properly designed. Of course, processing methods and their effect on nutritional components must be carefully considered as they play a major role in health promotion and disease risk reduction. Therefore important aspects related to production technologies, absorption, bioavailability, metabolism and personalized nutrition with consideration of gut microbiota need to be carefully examined.

The journal aims to provide an excellent platform to publish insightful findings of high-quality manuscripts as original research, reviews and opinion pieces. The editorial board consists of internationally renowned scientists whose commitment to the journal ensures the unbiased, constructive, and timely delivery of peer reviews. For details about the journal, especially the Guide to Authors, please visit the website: http://fppn.biomedcentral.com/.The journal intends to publish several articles each month online and each in a printed form on a quarterly basis.

We are grateful to all contributors, reviewers and board members as well as all those who gave their

\footnotetext{
* Correspondence: fshahidi@mun.ca

${ }^{1}$ Memorial University of Newfoundland, St. John's, Canada

Full list of author information is available at the end of the article strong support that made it possible to launch the inaugural issue of the journal. This issue includes the following articles.

In the article on the relevance of di- and tripeptides in bioactivities and taste of dry-cured ham, Toldra and coworkers from Spain demonstrated that small peptides exhibited strong ACE and DPP inhibitory activities and rendered a bitter taste to the products. Thus, they demonstrated that their empirical approach by using bioinformatics was able to successfully predict bioactivity of biopeptides with taste effects in dry-cured ham.

In an article by Liang et al., the authors examined the phytochemicals and antioxidant potential of different varieties of head cabbages produced in China and demonstrated that they were important to health due to their high content of phenolic acids, flavonoids as specifically anthocyanins in red head cabbage. As expected, the presence of isothiocyanates in the tested head cabbages was noticeable and their content varied among different varieties.

The article on the polyphenol composition and antioxidant activity of mint leaves by Brown et al. carefully examined the role of soluble and bound phenolics in two varieties of mint leaves and reported on different phenolic compounds present, with rosmarinic acid being an important one. The anti-inflammatory activity of the extracts, their effect on the inhibition of DNA scission and LDL oxidation in vitro provided sufficient information to allow further investigation in in vivo studies.

We trust that you find the very first set of papers interesting and invite you to submit your manuscript to the journal to share your findings with others. We look forward to receiving your submissions.

\section{Acknowledgements \\ Not applicable.}

\section{Authors' contributions}

The author FS and JS wrote the editorial. Both authors read and approved the final manuscript.

Funding

Not applicable. 
Availability of data and materials

Not applicable, no data concerned.

Ethics approval and consent to participate

Not applicable.

Consent for publication

Not applicable.

\section{Competing interests}

The authors declare that they have no competing interests.

Author details

'Memorial University of Newfoundland, St. John's, Canada. ${ }^{2}$ Institute of Food

Safety and Nutrition Jiangsu Academy of Agricultural Sciences, Nanjing,

Jiangsu, China.

Received: 2 August 2019 Accepted: 2 August 2019

Published online: 03 September 2019

\section{Publisher's Note}

Springer Nature remains neutral with regard to jurisdictional claims in published maps and institutional affiliations.

Ready to submit your research? Choose BMC and benefit from:

- fast, convenient online submission

- thorough peer review by experienced researchers in your field

- rapid publication on acceptance

- support for research data, including large and complex data types

- gold Open Access which fosters wider collaboration and increased citations

- maximum visibility for your research: over $100 \mathrm{M}$ website views per year

At BMC, research is always in progress. 